\title{
Is Charitable Giving Political? New Evidence from Wealth and Income Tax Returns*
}

\author{
Julia Cagé ${ }^{\dagger}$ Malka Guillot ${ }^{\ddagger}$
}

June 30, 2021

\begin{abstract}
What are the determinants of philanthropic and political giving? Are donations to charities and parties driven by the same incentives? In this article, we use new administrative household panel data to quantify empirically the motivations for giving, depending on donors' characteristics and tax incentives. Our dataset includes all the households filling their income tax and/or their wealth tax returns in France between 2006 and 2019. In France, both charitable and political donations benefit from income tax deductions, but only the charitable ones are eligible to the wealth tax credit. We exploit the 2018 wealth tax reform - a change in the taxable base that led to a drop by two third in the number of liable households - to estimate the cross-price elasticity of charitable and political giving at different levels of the income and wealth distributions. We provide new evidence of substituability between charitable and political donations: according to our estimates, a one-percent increase in the price of charitable giving leads to a 19 to $25 \%$ increase in political donations. The magnitude of this effect is particularly strong among the the top $20 \%$ of the wealth taxpayers.
\end{abstract}

Keywords: charitable giving, political donations, tax incentives for giving, tax deductions, wealth tax credit, cross-elasticity of donations

JEL No: H24, H31, L38

${ }^{*}$ We are grateful for the valuable comments from Gabrielle Fack, Elise Huillery and Lukas Schmid. We also thank seminar participants at the University of Lucerne and at the University Paris Dauphine - PSL. Romane Surel provided outstanding research assistance. The research leading to this project has received funding from the European Research Council under the European Union's Horizon 2020 research and innovation programme (Grant Agreement no. 948516). It is also supported by a public grant overseen by the French National Research Agency (ANR) as part of the "Investissements d'avenir" program (reference: ANR-10-EQPX-17 - Centre d'accès sécurisé aux données - CASD). An online Appendix with additional empirical material is available here. All errors remain our own.

${ }^{\dagger}$ Sciences Po Paris and CEPR (julia [dot] cage [at] sciencespo [dot] fr).

${ }^{\ddagger}$ Center for Law and Economics, ETH Zurich (malka [dot] guillot [at] gess [dot] ethz [dot]ch). 


\section{Introduction}

There has been a rise in charitable giving in Western democracies in recent years. In the United States, according to the statistics provided by Giving USA $^{1}$ charitable giving has increased by $121 \%$ between 2000 and 2019 - from 203 billions dollars to 450 billions; in Switzerland, we similarly observe a 78.3\% increase between 2003 and 2019 and in France, a $78.6 \%$ increase between 2006 and 2019, from 1.465 to 2.617 billion euros. ${ }^{2}$ How to explain such an increase? First, tax policies in many Western democracies increasingly offer substantial incentives to donate to charities. This increase has also been related to individuals' growing desire to be seen to be doing good (e.g. the so-called warm-glow motive for giving described by Andreoni, 1989, 1990). Yet, philanthropy may not be just about giving, and can also serve political objectives (see e.g. Reich, 2018; Bertrand et al., 2020a). In many countries, such as the U.S., we observe a concomitant increase in political donations. This raises the question of how these two types of givings intertwine.

In this article, we study the determinants of both charitable and political giving. While there is an extensive literature estimating the tax-price elasticity of giving and the impact of tax incentives to donate to charity (Bakija and Heim, 2011; Fack and Landais, 2016b; Almunia et al., 2020), little is known on the political motivations underlying contributions to charitable activities. To investigate whether donations to charities and political parties are driven by the same incentives, we use new administrative household panel data. Our dataset includes all the households filling their income tax and/or their wealth tax returns in France between 2006 and 2019, i.e. around 39 million households per year that we can follow over time and across wealth and income tax returns thanks to a unique household identifier.

In France, charitable and political donations of households can benefit from tax deductions that are relatively generous in international comparisons. On the one hand, charitable and political giving can benefit from a nonrefundable income tax credit equal to $66 \%$ of the gift. ${ }^{3}$ On the other hand, charitable donations (but not the political ones) can benefit from a wealthtax reduction equal to $75 \%$ of the amount of the donations made (up to a limit of $€ 50,000$ per year ${ }^{4}$ ). Taxpayers liable to the wealth tax can choose to declare their charitable donations either to the wealth tax or to the income tax (but they cannot declare it twice). Further, while donations to parties and electoral campaigns are capped, charitable donations are not but can nonetheless benefit politically-involved nonprofit organizations, think tanks to begin

\footnotetext{
${ }^{1}$ https://givingusa.org/

${ }^{2}$ According to the authors' own calculations. See Section 3 below for detailed information about the data sources.

${ }^{3}$ The gift can be deducted up to a ceiling currently equal to $20 \%$ of taxable income. See Section 2 below for more details.

${ }^{4}$ However, households are offered the possibility to fiscally report excess donations from one year to the other.
} 
with (Cagé, 2018). ${ }^{5}$ France thus provides a unique empirical framework to investigate whether donations to charities and to parties are substitutes or complements.

Estimating the cross-elasticity of political and charitable donations raises a number of empirical challenges, reverse causality to begin with. What's more, omitted variables such as the intrinsic generosity or the political ideology of the donors can also bias naive estimates. In this article, we overcome these challenges by proposing a new instrumental strategy exploiting a tax reform. In 2018, the solidarity tax on wealth ${ }^{6}$ became a real-estate tax ${ }^{7}$. This reform did not modify the tax schedule but restricted the definition of the tax base to real-estate assets, excluding other investments (in particular financial assets) which were previously included. With this transformation of the wealth tax into a tax on housing assets, two thirds of the households liable to the wealth tax on their 2016 wealth are not liable for their 2017 wealth anymore, and thus can no longer benefit from the $75 \%$ wealth-tax deductions for charitable giving. ${ }^{8}$ In other words, the reform created a shock on the price of charitable giving - that increases from 25 to $34 \%$ of the amount of the gift given the income tax credit is "only" equal to $66 \%$ of the donations ${ }^{9}$ - but not on the price of political donations, given political giving was not eligible to the wealth-tax deduction before the reform.

In practice, we proceed as follows: we use the 2018 wealth tax reform as an instrument for the price of charitable giving in the first stage of the estimation ${ }^{10}$, and then investigate in the second stage how the (instrumented) price of charitable giving affects political giving. "Treated" households are those households who were liable to the wealth tax in 2016 but not in 2017 and beyond because of the tax reform, while the "control" group is made of the households liable to the new wealth tax and who can thus still benefit from the $75 \%$ wealth-tax deduction following the reform. Our identification assumption is that, given political giving was not eligible to wealth tax deductions and thus not directly affected by the reform, the 2018 wealth-tax reform only affected political donations through its effect on the tax price of charitable giving.

The main threat to our empirical strategy comes from the fact that the wealth-tax reform led to a decrease in the amount of taxes paid for the households in the treated and the control group $^{11}$, i.e. an increase in the resources at their disposal (a phenomena that we can approach

\footnotetext{
${ }^{5}$ Even charitable donations to non politically-involved foundations can be driven by political motives, e.g. buying access and time. We will come back to this point later.

${ }^{6}$ ISF or "impôt de solidarité sur la fortune" in French.

${ }^{7}$ IFI or "impôt sur la fortune immobilière".

${ }^{8}$ In France, a wealth tax for year $t$ is levied on the wealth evaluated at the end of year $t-1$, so that the 2018 reform is effective from the 2017 wealth on.

${ }^{9}$ Compared to $75 \%$ for the wealth-tax credit.

${ }^{10}$ The price of charitable giving corresponds to the cost of giving an additional euro: $25 \%$ if the household is liable to the wealth $\operatorname{tax}, 34 \%$ if the ceiling of the wealth tax deduction is reached, 0 if the income tax cap is reached (see Section 3.3 for detailed explanations). As a result of the low variation in the price, its correlation with the instrument is very high, which ensures that the estimation is not threatened by a weak instrument issue.

${ }^{11}$ We observe a decrease of $€ 10,820$ and $€ 7,702$ for households in the control and treated group, respectively.
} 
just like a positive "income effect"). This positive shock might have had a direct effect on either or both political and charitable donations through a resource effect (with more cash at their disposal, households decide to contribute more ${ }^{12}$ ).

First, we compute for the households in both the treated and the control group the amount of taxes saved thanks to the reform, and show that controlling for this amount only slightly decreases the estimated price elasticity of political giving. Then, we turn to a more conservative approach where we only consider in our instrumental variable analysis treated and control households who face approximately the same tax saving. While doing so reduces the size of our sample, it does not affect our main findings qualitatively.

Overall, we show that a one-percent increase in the price of charitable giving leads to a $25.4 \%$ increase in political donations. In other words, consistently with findings by Petrova et al. (2020) who deduce substituability from the fact that households react differently to natural disasters and to political ads in their giving behavior, we show that charitable and political giving as substitutes. ${ }^{13}$ The estimated elasticity is equal to $19 \%$ when we reduce our sample of analysis to the households who face a similar tax saving. Our findings are robust to a number of different empirical specifications and robustness checks.

The magnitude of the effects is heterogeneous depending on the wealth of the households (considered before the reform) as well as on their income. In particular, our estimates are nearly three times larger among the top $20 \%$ wealth tax payers compared to the other households, and this difference is statistically significant.

Our results have important policy implications. If donations to charities are (at least) partly driven by political considerations, then one might question the relevance of having different tax deductions for charitable and political giving. Next, given political donations are capped in France (as well as in a number of other countries) to assure political equity, it may also be relevant to limit (politically-driven) charitable contributions. We discuss the welfare implications of our results at the end of the paper.

Literature review Our paper first contributes to the long tradition of research analyzing philanthropic giving, and in particular estimating the tax-price elasticity of giving (Feldstein and Taylor, 1976; Randolph, 1995; Bakija and Heim, 2011; Andreoni and Payne, 2013). ${ }^{14}$

\footnotetext{
${ }^{12}$ See for example Bakija and Heim (2011) who show that the elasticity of charity with respect to a persistent income change is equal to 0.51 .

${ }^{13}$ This finding contradicts Yörük (2015) however. While Yörük (2015) relies on cross-sectional household surveys of donations in the U.S. between 1990 and 2001, we use panel data that allow us to follow households over time. We can thus exploit a shock on the price of charitable giving to causally identify how households adjust their political donations, using within-household variations. Interestingly, when we simply consider the raw relationship between the price of charitable giving and political donations, without household-level controls, we find no statistically significant correlation. Instrumenting for the price of giving allows us to uncover the fact that political and charitable donations are substitute. Yörük (2015) uses the tax price of giving as an instrument for charitable donations, but does not instrument for this price.

${ }^{14}$ See also Bakija (2013) and Fack and Landais (2016a) for a literature review on tax policy and philanthropy.
} 
Several articles in this literature have estimated the effect of tax incentives for charitable contributions. Fack and Landais (2010) use two reforms in France that increased the nonrefundable tax credit rate in 2003 and 2005, and Fack and Landais (2016b) exploit the 1983 tightening of the requirements to claim charitable deductions. ${ }^{15}$ Fack and Landais (2010) find that the elasticity price of gifts is around -0.2 to -0.6 depending on income; in the U.S. context, Bakija and Heim (2011) estimate an elasticity in excess of -1 .

Compared to this literature, our contribution is fourfold. First, while the focus of these papers is on charitable contributions, we also consider political donations that benefit from similar tax incentives but may be driven by different motivations. Campaign contributions and charitable giving are indeed most often not analyzed in conjunction, while they may be considered as the two sides of the same coin. ${ }^{16}$ An exception is Petrova et al. (2020) who provide evidence that individuals substitute between political contributions and charitable contributions using data from the US and shocks on charitable and political giving (see also Yörük (2015) who uses survey data to investigate the spillover effects of charitable subsidies on political giving in the US between 1990 and 2001 and finds complementarity between the two kinds of donations). ${ }^{17}$ We contribute to this literature by looking at substitution effects within the same donors. Our data indeed allow us to investigate at the taxpayer level the propensity of individuals to contribute to both political parties and charities and, thanks to our empirical strategy, we can isolate the causal effect of an increase in the price of charitable giving (driven by a change in tax incentives) on political donations (not affected directly by this change). ${ }^{18}$

Second, while the focus of the existing literature has been on the income tax, our paper

\footnotetext{
${ }^{15}$ See also Doerrenberg et al. (2017) who exploit several tax reforms implemented in Germany between 2001 and 2008 to estimate both the elasticity of taxable income and the elasticity of deductions with respect to net-of-tax rate. In the French context, Guillot (2019) and Aghion et al. (2019) study behavioral responses to changes in taxation.

${ }^{16}$ Ansolabehere et al. (2003) argue, for example, that both political and charitable giving should be regarded as a form of consumption. There is a growing literature that examines the non-tax determinants of donations, whose primary focus is on changes in societal needs: Deryugina and Marx (2020), using deadly tornadoes, find that giving to one cause needs not come at the expense of another; Fong and Luttmer (2009) investigate the role of racial group loyalty in the context of donations to hurricane Katrina victims (on giving to disasters, see also Scharf et al., 2017). Next, DellaVigna et al. (2012) and Andreoni et al. (2017) investigate the importance of the social context, and in particular of social pressure in charitable giving.

${ }^{17}$ Hungerman et al. (2018) investigate the effect of campaign activity on non-political donations, and document an increase in collections for nearby churches the week following a campaign stop by a presidential candidate.

${ }^{18}$ There is a large literature on the determinants of campaign contributions (for a literature review, see Dawood, 2015), but this literature mostly overlooks the issue of the tax price of political giving. This is mostly due to the fact that political donations in the US do not give rise to tax deductions - while it is the case in France (as well as in many others Western democracies), and so can be studied in our context. The main determinants of campaign donations that have been highlighted in the literature are political influence (see Gordon et al. (2007); Chamon and Kaplan (2013); Barber (2016) for empirical evidence, and Grossman and Helpman (1994, 1996) for the leading theoretical models); the willingness to affect election outcomes (Poole and Romer, 1985; Wand, 2007); a consumption motive (Ansolabehere et al., 2003; Gimpel et al., 2008); and the effect of political advertising (see e.g. Green et al., 2015, on the impact of non partisan messages).
} 
also exploits variations in the wealth tax and estimates cross-price elasticity of giving. While there exists a very large literature investigating the impact of wealth taxation (Brülhart et al., 2016; Seim, 2017; Jakobsen et al., 2019), to the extent of our knowledge, we are the very first to study the extent to which wealth-tax deductions impact donations. Furthermore, while the existing research mostly considers direct variations in the price of giving (through changes in the tax treatment donations benefit from), we consider indirect shocks (exploiting a wealth tax reform).

Third, while the existing research mostly uses survey data ${ }^{19}$, sample of tax payers ${ }^{20}$ or focuses on the top of the income distribution when using tax returns, we rely on an exhaustive administrative panel dataset and estimate the elasticities at different levels of the distribution. ${ }^{21}$ Almunia et al. (2020) similarly use administrative tax return data (from the UK) and exploit a tax reform. But while they only consider the income tax and focus on charitable giving, we study both income and wealth tax in this paper, and investigate whether there are substitution effects between charitable and political donations.

Finally, this paper also contributes to the growing literature on the political economy of charitable giving. In the US context, Bertrand et al. (2020a) analyze the role of charitable giving as a means of political influence. They estimate that 16.1 percent of total US corporate charitable giving can be interpreted as politically motivated (see also Bertrand et al., 2018). ${ }^{22}$ Compared to this work, we contribute to the literature by estimating whether charitable giving and political donations act as substitutes or complements. This is of particular importance in contexts where political donations are limited, but not charitable contributions.

The rest of the paper is organized as follows. In Section 2 below, we provide historical background on tax deductions for charitable and political contributions in France, and describe the tax reforms that took place during our period of interest. Section 3 presents the unique panel data we use in this article, provides descriptive statistics and describe our identification strategy. Section 4 presents the main results, their robustness, and investigate the heterogeneity of the effect across various dimensions. In Section 5 we discuss our findings and their policy implications. Section 6 concludes.

\footnotetext{
${ }^{19}$ Among others, Brown and Lankford (1992); Scharf and Smith (2015); Yörük (2015); Backus and Grant (2016).

${ }^{20}$ E.g. Fack and Landais (2010) use a repeated cross-section of 500,000 tax payers drawn every year by the tax administration; Bakija and Heim (2008) relies on a panel of 550,000 disproportionately high-income ax returns.

${ }^{21}$ A strand of the literature also relies on charities' tax filings. See in particular Duquette (2016).

${ }^{22}$ For a review of the most recent empirical literature on lobbying in political economy, see Bombardini and Trebbi (2020). See also Fioretti (2020).
} 


\section{Historical background}

In this section, we first describe the French regulatory background for charitable and political contributions. We then outline the main tax reforms that took place during our period of interest (2006-2019). The time period considered is determined by data availability reasons: the wealth tax return data at the households level are only available between 2006 and 2019 .

\subsection{Tax deductions for charitable and political contributions}

Tax incentives for charitable giving were introduced relatively late in France in international comparison, but with much higher rebates (Fack and Landais, 2016a; Fack et al., 2018). To understand these rebates and their evolution over time, one first needs to distinguish between different kinds of donations: (i) charitable giving, (ii) donations to charities fighting against poverty (the so-called "dons Coluche"), and (iii) political donations.

\subsubsection{Income tax credit}

Tax credit for charitable giving A tax incentive toward charitable giving has existed in France since 1954, but has been significantly modified over time (Fack and Landais, 2010). The initial deduction mechanism, which worked as a deduction from taxable income, was replaced in 1989 by a nonrefundable tax credit of 40 percent. With a nonrefundable tax credit, all taxpayers benefit from the same tax credit rate equal to $\mathrm{x} \%$ of the gift, regardless of their income level. However, the gift can only be deducted up to a ceiling currently equal to $20 \%$ of the taxable income. ${ }^{23}$ Further, given the tax credit is nonrefundable, the deduction cannot exceed the income tax that is due for taxable households.

The tax credit rate was raised three times since the late 1980s: from 40 to 50 percent in 1996, from 50 to 60 percent in 2003, and from 60 to 66 percent in $2005^{24}$, a rate that has been unchanged since then.

Tax credit for Coluche giving In 1989, a specific rate was created for the donations to charities that help people in need - and that we will call "Coluche giving" from now. ${ }^{25}$ These donations - that have to be below a certain threshold (€546 in 2019) - benefit from a nonrefundable income tax credit of $75 \%$ percent. ${ }^{26}$

\footnotetext{
${ }^{23}$ However, if the gift exceeds the ceiling, its reporting can be spread out over five years. We will come back to this point later.

${ }^{24}$ Fack and Landais (2010) exploit the 2003 and 2005 reforms.

${ }^{25}$ Coluche is a French stage comedian and cinema actor who launched in 1985 the charity "Les Restaurants $d u$ Coeur". This nonprofit organization provides free meals and other products to people in need.

${ }^{26}$ This rate was equal to $50 \%$ at the time of its creation; it then increased from 50 to $60 \%$ in 2003 and from 60 to $75 \%$ in 2005 .
} 
Tax credit for political giving Political donations, i.e. donations to political parties and to campaigns, are allowed in France since 1988 (Cagé, 2018; Bekkouche et al., 2020). Tax deductions for these donations were introduced at the exact same time, with the same rate than for other charitable donations (i.e. a $66 \%$ nonrefundable income tax credit). However, contrary to charitable donations, political donations are limited by law in France. A natural person may contribute up to $€ 4,600$ to each campaign, and donate an annual maximum of $€ 7,500$ to political parties or groups. ${ }^{27}$

We observe donations to political parties directly in the income tax returns data since 2013 (they were previously bundled with charitable donations ${ }^{28}$ ). We report descriptive statistics on these donations in Section 3.2 below. One can also study the aggregate change in political donations by using the accounts of the political parties that have to report annually the donations they receive. Online Appendix Figure C.5 plots this number. Consistently with what we observe in Figure C.4 using the fiscal data, we observe a decrease in this number in recent years.

Note that taxpayers report their charitable, Coluche and political giving on the same page of their income tax form, but on three different rows ("7UD", "7UF" and "7UH"; see online Appendix Figure C.1 for an illustration).

\subsubsection{Wealth tax credit}

The wealth tax credit for charitable donations - political donations are not eligible to this tax credit - was introduced in 2007 as part of the "loi TEPA", a fiscal package aiming at lightening the fiscal burden on businesses, liberalize the labor market and stimulate investment. Interestingly, section 6 of this Law - introducing the wealth-tax deductions - went relatively unnoticed at the time, with virtually no media coverage. ${ }^{29}$ The wealth tax credit was very generous, though, with a wealth-tax reduction equal to $75 \%$ of the amount of the donations made, up to a limit of $€ 50,000$ per year. ${ }^{30}$

\footnotetext{
${ }^{27}$ Corporations are not allowed to contribute to political parties or campaigns since 1995 (Bekkouche et al., 2020). Until 2012, individuals were allowed to give annually $€ 7,500$ to each of the political parties of their choice. The rule was changed in $2012-€ 7,500$ overall, taking into account the donations made to all the political parties - because parties were increasingly creating micro-parties to augment the donations they could receive.

${ }^{28}$ Donations to electoral campaigns are still bundled with charitable donations in the tax data as of today. We provide below descriptive statistics on these donations that we compute from the electoral campaign records.

${ }^{29}$ We have gone through all the articles published by the five main daily newspapers (Le Monde, L'Humanité, La Croix, Le Figaro, and Libération) at the time about the law, and found nearly no mention of section 6 . All the media attention was focused on Articles 1 to 4 of the law that introduced a tax exemption for overtime, a reform of the inheritance tax, a change of the tax shield, and an experimentation of the "active solidarity revenue" (RSA).

${ }^{30}$ There were also very few discussions at the time in the Parliament about this specific section of the law to the exception of some debate about whether political donations should also benefit from it. In particular, no specific estimation was made of the cost of the reform The only estimation provided was the joint estimated cost of this reduction together with other measures in favors of the SMBs (overall, the estimated cost was equal to $€ 410$ million per year).
} 
Note that taxpayers liable to the wealth tax can choose to declare their charitable donations either to the wealth tax or to the income tax, but they cannot declare it twice. However, contrary to the income tax credit, not all nonprofit organizations are eligible to the wealth tax credit. Indeed, only a subset of the nonprofit organizations that are recognized as "being of public utility" (the so-called "Fondations Reconnues d'Utilité Publique" or FRUP) can benefit from it, as well as the non-profit research, higher education or artistic institutions of general interest.

As of today, there exist 661 FRUPs. While this number might seem small, in particular compared to the 1.3 million associations that exist in France, it turns out not to be. Indeed, while the majority of the associations are very small structures, with nearly no funding and most often no employees, the FRUPs tend to be much larger and represent from this point of view a more important part of the non-for-profit sector in France. Two thirds of the associations have annual budgets of less than $€ 7,500$, and only $5 \%$ of the associations have an annual budget of more than $€ 150,000 .{ }^{31}$ On the contrary, to become a FRUP, a foundation needs to have an endowment of at least $€ 1.5$ million. ${ }^{32}$ We will come back to this point in Section 5.2 below, where we discuss the political dimension of a number of foundations.

\subsection{The 2018 wealth tax reform}

The goal of this paper is to estimate the cross-elasticity of political and charitable donations. However, doing so raises a number of empirical challenges given reverse causality and omitted variable bias. To obtain a causal estimate, we propose in this article to exploit the 2018 wealth tax reform. ${ }^{33}$ We present our empirical strategy in Section 3 below; here, we simply describe the reform.

In 2018, the solidarity tax on wealth became a real-estate tax. While the tax schedule was unchanged ${ }^{34}$, the taxable base was: compared to the previous solidarity tax on wealth, the real-estate tax only covers real-estate assets and excludes other investments (in particular financial assets). Because of the reform, two thirds of the households who were liable to the wealth tax in 2016 are not liable in 2017 anymore, i.e. 238,564 out of 356, 227 households.

Hence, this wealth tax reform led to a drop in the number of households liable to the wealth tax, and so to the number of households eligible to the wealth-tax deduction. For the

\footnotetext{
${ }^{31}$ According to the Ministry of the interior: https://www.associations.gouv.fr/ les-associations-en-france.html\#Les-chiffres. $92 \%$ of the associations have annual budgets of less than $€ 75,000$.

${ }^{32}$ Law n87-571 of July 23, 1987 on the development of patronage.

${ }^{33} \mathrm{~A}$ number of other tax reforms took place during our period of interest, that we do not use in this article but describe in the online Appendix Section B.

${ }^{34}$ Are liable to the wealth tax, only the households whose net taxable wealth is above $€ 1.3$ million. The tax rates is equal to (i) $0 \%$ between $€ 0$ and $€ 800,000$, (ii) $0.5 \%$ between $€ 800,000$ and $€ 1,300,000$, (iii) $0.7 \%$ between $€ 1,300,000$ and $€ 2,570,000$, (iv) $1 \%$ between $€ 2,570,000$ and $€ 5,000,000$, (v) $1.25 \%$ between $€ 5,000,000$ and $€ 10,000,000$, and (vi) $1.5 \%$ above $€ 10,000,000$.
} 
households no longer liable to the wealth tax following the reform, it also implied an increase in the price of charitable giving - given they could no longer benefit from the $75 \%$ wealth-tax credit - but no changes for political donations, which have never been eligible to this credit.

\section{Data, descriptive analysis and identification strategy}

The data are from the General Directorate of Public Finance, and is made available through the CASD ("Centre d'accès sécurisé aux données"). We briefly describe the dataset here and provide more details on data construction in the online Appendix Section A.

\subsection{Panel dataset}

Our dataset includes all the households who must declare their taxes in France, i.e. all the households filling their income tax and/or their wealth returns. In France, an individual must file an annual tax return if she is in one of the following situations: (i) she resides in France, (ii) her main professional activity is in France, (iii) she turned 18 in year $N$ and she is no longer attached to her parents' tax household, (iv) she lives abroad but her income is from a French source. The tax return is mandatory regardless of the amount of her income, even if it is zero or low. ${ }^{35}$ Overall, around 38.5 million households file an income tax return as of 2018. There is a single tax return per tax household, unless there is a change of the household definition during the year (e.g. because of a marriage or a divorce). For single persons (single, divorced, widowed, cohabiting) the tax household is made up of the taxpayer and her dependents. For married and civil union partners, the tax household consists of the taxpayer, his/her spouse and dependents. The income and expenses of all members of the tax household are taken into account to establish a single tax assessment (in the empirical analysis below, we always control for the number of fiscal shares).

Regarding the wealth tax, since $2018^{36}$, are required to file a declaration the individuals whose real estate assets have a net taxable value strictly superior to the tax threshold, i.e. $€ 1,300,000$. An individual domiciled outside of France for tax purposes (and so not filling an income tax return) has to file a wealth-tax declaration if her real estate assets and rights located in France ${ }^{37}$ are above $€ 1,300,000^{38}$. In the online Appendix Figure C.2, we report

\footnotetext{
${ }^{35}$ Note that in 2019, a reform introduces the "prélèvement à la source" or tax withholding in France. Before January 2019, French tax residents paid income tax on their wages via self-assessment; income tax was payable after completion and submission of the tax return and employers were not involved in this collection. Since January 2019, the income tax is paid to the government by the payer of the income rather than by the recipient of the income. However, this new income tax withholding did not change the obligation to fill the tax return.

${ }^{36}$ As we already noted, the wealth tax was reformed a number of times during our period of interest - reforms that we exploit in our empirical analysis. Some of these reforms directly modify the reporting obligations.

${ }^{37}$ As well as her shares in companies or organizations (established in France or abroad) for the portion of their value representing these real estate assets or rights.

${ }^{38} 1.4 \%$ of the households filling a wealth-tax return are not liable to the French income tax.
} 
Table 1: Descriptive statistics: characteristics of the households (2016)

\begin{tabular}{lcccccc} 
& Mean & Std. Dev. & p25 & p50 & p75 & Frac. > 0 \\
\hline Taxable income & 25,544 & 38,559 & 10,562 & 18,643 & 32,209 & 0.93 \\
Number of fiscal dependents & 1.8 & 0.9 & 1.0 & 2.0 & 2.0 & 0.28 \\
Age (individual 1) & 51 & 19 & 35.0 & 50.0 & 65.0 & 1.00 \\
Donations (income tax) & 70.7 & $15,561.0$ & 0.00 & 0.00 & 0.00 & 0.14 \\
Non-political donations (income tax) & 68.5 & $15,560.2$ & 0.00 & 0.00 & 0.00 & 0.14 \\
Political donations (income tax) & 2.2 & 93.8 & 0.00 & 0.00 & 0.00 & 0.0077 \\
Reduction for donation (coluche - 75\%) & 7.5 & 44.7 & 0.00 & 0.00 & 0.00 & 0.044 \\
Reduction for donation (general - 66\%) & 30.8 & 593.6 & 0.00 & 0.00 & 0.00 & 0.094 \\
\hline
\end{tabular}

Observations

$37,828,568$

Notes: The table shows descriptive statistics for the characteristics of the households declaring an income tax return in 2016. All the variables but age (in years) and the number of fiscal dependents are in euros.

the evolution of the number of households filling their income tax and/or their wealth returns during our period of interest.

Thanks to a unique household identifier, we follow households over time for both income and wealth tax. Our tax return data contains information on households' composition, detailed income composition, wealth ${ }^{39}$ (if they fill a wealth-tax return), and all reductions and rebates claimed. The data also contains output variables of the income tax computation such as the tax due and the amounts deduced for it. In this article, we are mainly relying on the information on income, wealth, charitable and political donations, department of residency, number of dependents and age as well as on the panel structure of the data. Table 1 provide summary statistics on these variables.

Regarding donations, more precisely, we have information on the total amount of donations eligible to income and wealth tax deductions, i.e. both charitable and political donations, that are declared by the households on their tax form(s). ${ }^{40}$

\subsection{Charitable and political donations}

As we highlighted above, donations can be declared either on the income tax form or on the wealth tax form for the households liable to both income and wealth tax. However, households cannot declare the same donation twice.

Figure 1 plots the evolution of the number of households who declare a donation during our period of interest. We observe a large increase in the number of households declaring a donation on their wealth-tax form (henceforward the wealth-tax donors, dashed red line) between 2008 and $2009^{41}$, a drop in 2010, and then a continuous increase until 2016. The drop

\footnotetext{
${ }^{39}$ Detailed wealth composition is available for the households liable to the wealth tax with a wealth above $€ 2,507,000$. Indeed, those with a wealth tax below $€ 2,507,000$ did not have to fill in a detailed wealth tax returns up to 2018.

${ }^{40}$ We do not observe in the data the detailed composition of the giving made by households.

${ }^{41}$ In 2006, this number is equal to 0 given the wealth tax deduction was introduced in 2007.
} 
Figure 1: Number of households who give

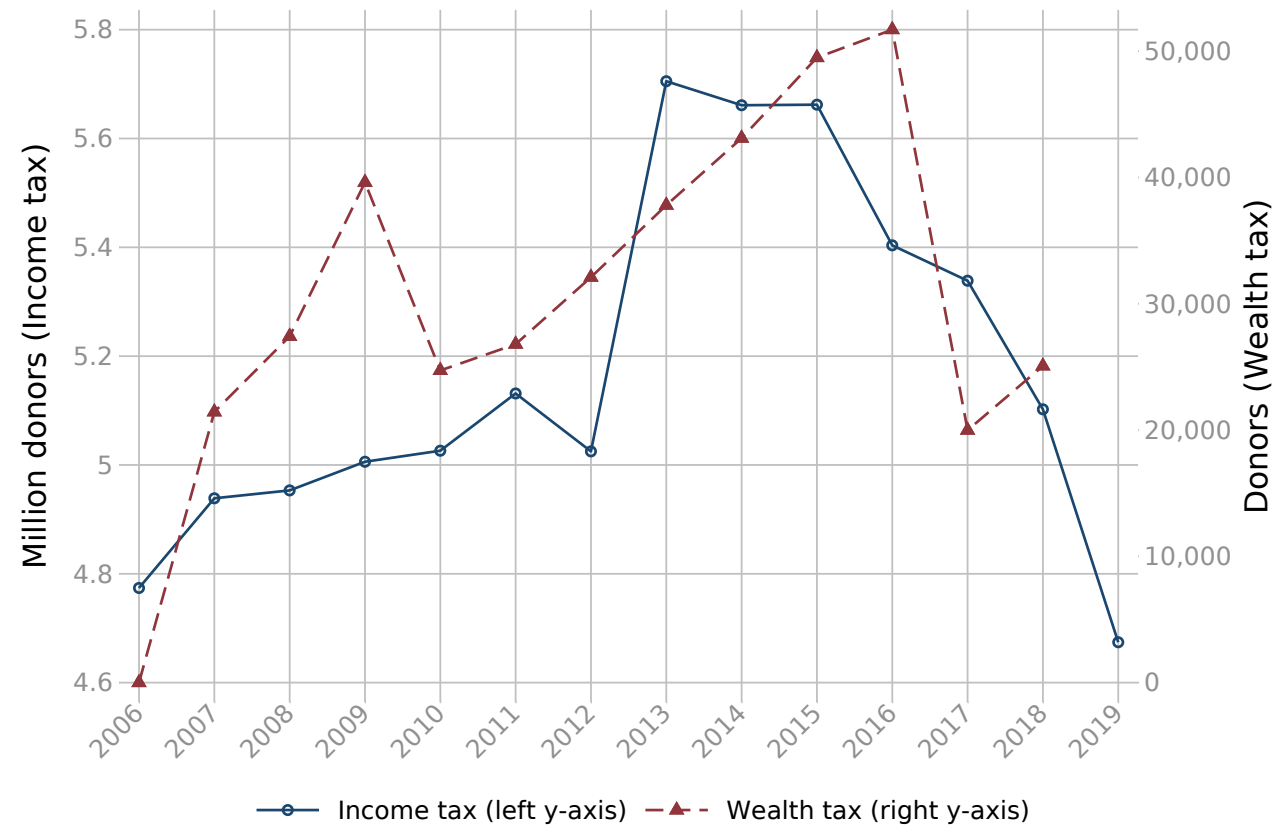

Notes: The Figure plots the evolution of the number of households who declare a donation on their income and wealth tax forms per year. The time period covered is 2006-2019. The number of income-tax donors is reported on the left $\mathrm{y}$-axis (blue line with dots) and the number of wealth-tax donors on the right y-axis (dashed red line with triangle).

in 2010 is most probably be due to the 2011 wealth-tax reform that increased the amount of net property assets above which individuals are liable for the wealth tax from $€ 0.8$ to $€ 1.3$ million (thus decreasing the number of liable households). ${ }^{42}$ Similarly, the 2017 drop can be explained by the 2018 wealth-tax reform that leads to a decrease in the number of liable donors.

However, while we observe a drop in the absolute number of wealth-tax donors in 2017, the share of donors among households liable to the wealth tax increases, as appears in the online Appendix Figure C.3. It is equal to 18\% in 2018, the last year for which we have data.

The picture is quite different if we consider the households who declare a donation on their income tax form (henceforward the income-tax donors). We observe a continuous decline in the share of donors for all three kind of donations since the mid-2010s, as illustrated in Figure 2. In 2019, around 9\% of the households declared a donation on their income-tax form compared to more than $12 \%$ in 2014 . Further, less than one percent of the households make a donation to political parties every year.

This decrease in the share of income-tax donors did not go with a decline in the amount of total donations, however. Figure 3 plots this amount for both the income-tax and the

\footnotetext{
${ }^{42}$ Contrarily to the 2018 reform, we cannot exploit in our empirical analysis the 2011 change given the data on political donations is only available since 2013.
} 
Figure 2: Income-tax donations: Share of households who give

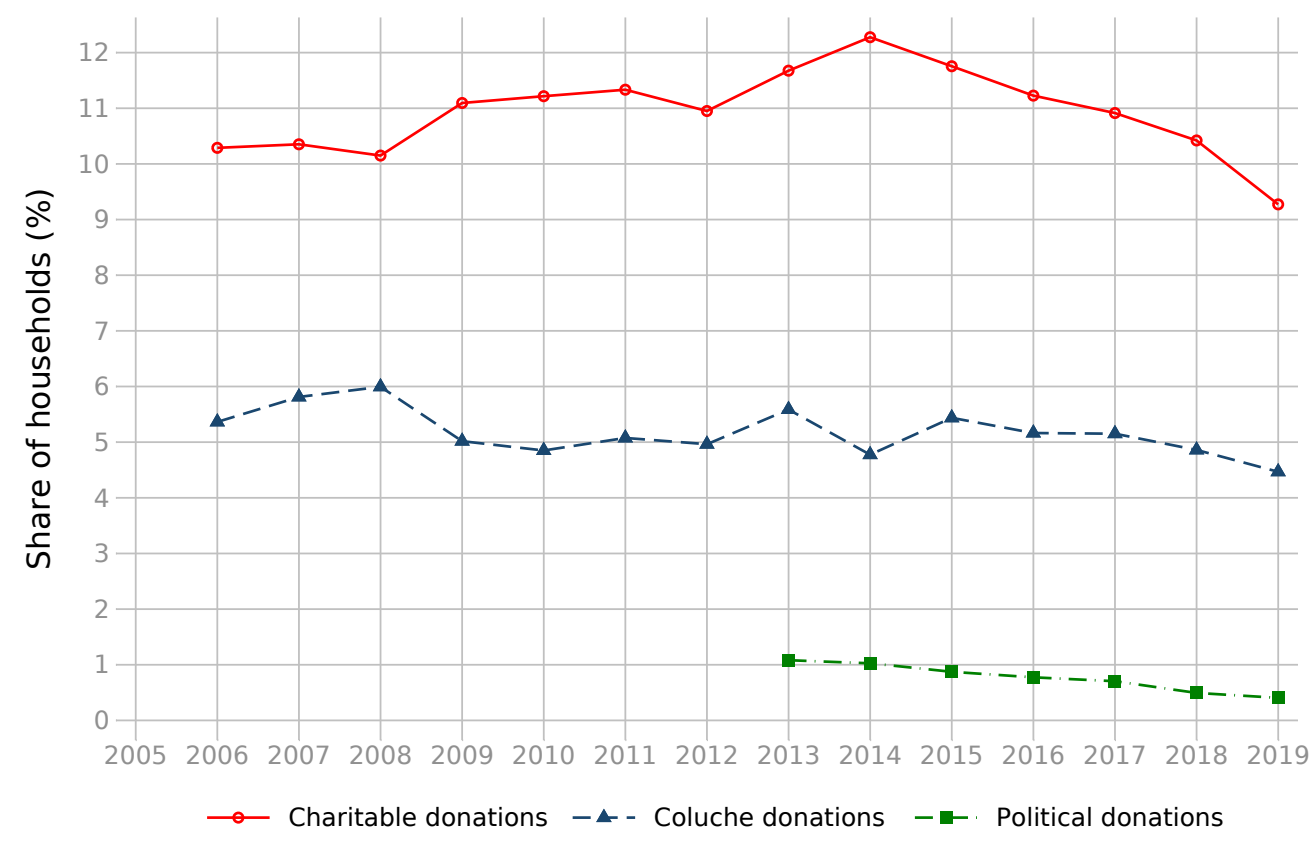

Notes: The Figure plots the evolution of the share of the households liable to the income tax who declare a donation on their income tax form per year. The time period covered is 2006-2019. The red line with dots plots this share for the charitable donations, the dashed blue line with triangles for the Coluche donations, and the dash-dot green line with squares for the political donations. 
Figure 3: Number of households who give

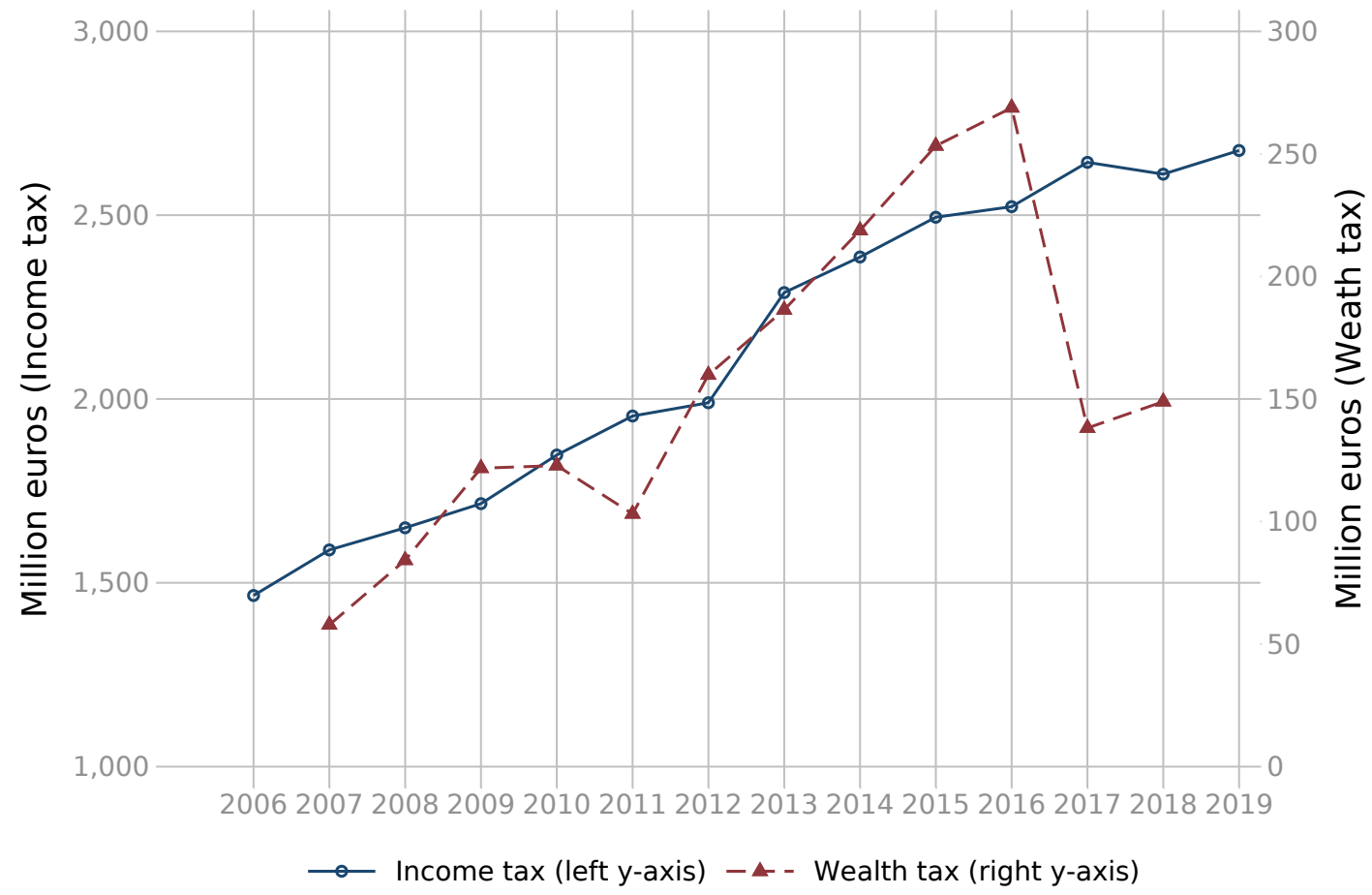

Notes: The Figure plots the evolution of the number of households who declare a donation on their income and wealth tax forms per year. The time period covered is 2006-2019. The number of income-tax donors is reported on the left $\mathrm{y}$-axis (blue line with dots) and the number of wealth-tax donors on the right y-axis (dashed red line with triangle).

wealth-tax donations. Income-tax donations have increased from around $€ 1.5$ billion in 2006 to more than $€ 2.6$ billion in 2019 (see online Appendix Figure C.4 for a decomposition by type of donations). This is due to the fact that the average amount declared has increased during the same time period, from $€ 150$ (€320 among donors) to $€ 400$ (€850 among donors) (online Appendix Figure C.6). While donations to electoral campaigns are not reported separately in the income tax form (they are bundled with the charitable donations), we can compute their aggregate amount from the campaign records. Online Appendix Figure C.8 reports these numbers. While we observe heterogeneity depending on the election considered, overall, campaign donations only account for a very small share of total charitable giving.

Last, note that contrarily to income-tax donations, the total amount declared to the wealth tax has decreased in recent years. This can be related to the 2018 wealth-tax reform we exploit in the paper; we will come back to this point when discussing our identification strategy.

Incentives to report One legitimate concern regarding the data we are using in the paper can come from the fact that, given the tax credit is non refundable, only the households who actually pay income tax (i.e. around half of the households) have a fiscal incentive to report 
their donations given they are the only ones who can benefit from the tax rebate. However, according to Fack and Landais (2010), given it is almost costless for a household to report its contributions, the vast majority of contributions to charities are reported in the tax data, even those made by nontaxable households.

Further, the focus of this article is on the households who were liable to the wealth tax in 2016; nearly all these households are also at the top of the income distribution and so do actually pay income tax. So, the possibility of misreporting is less of a concern for us given our empirical setting.

\subsection{Empirical challenges and identification strategy}

The goal of this paper is to estimate the cross-elasticity of charitable and political giving, i.e. the following equation:

$$
\text { political giving }_{i, t}=\beta_{0}+\beta_{1} \text { charitable giving }_{i, t}+\mathbf{X}_{\mathbf{i}, \mathbf{t}}^{\prime} \boldsymbol{\beta}_{\mathbf{2}}+\eta_{i}+\gamma_{t}+u_{i t}
$$

where $i$ indexes the households and $t$ the years. Doing so raises a number of empirical challenges, given the endogeneity of charitable giving in political giving behaviour, and the bias that can arise from omitted variable (e.g. the intrinsic generosity or political ideology of the donors ${ }^{43}$ ) To overcome these challenge, we propose a new instrumental variable approach based on a reform affecting the tax price of (charitable) giving.

\subsubsection{The 2018 wealth tax reform and the change in the price of giving}

More precisely, we use the 2018 wealth tax reform described in Section 2.2 above as an instrumental variable. This reform transformed the existing wealth tax (ISF) into a tax on housing assets $(I F I)$. Following it, two thirds of the households liable to the wealth tax in 2016 were no longer liable in 2017, and so can no longer benefit from the $75 \%$ wealth-tax deduction on their charitable donations. In other words, for these households, this reform was a shock on the price of charitable giving. However, it did no directly affect political donations, given political donations were not eligible to the wealth-tax deduction before the reform (nor after).

We thus focus on the 356,227 households who were liable to the wealth tax in 2016. Table 2 presents descriptive statistics for these households in 2016. On average, the households in our sample had an annual income ${ }^{44}$ equal to $€ 135,227$ in 2016 , and a total gross wealth of $€ 3,015,480$. The average amount of charitable donations declared by these households on their income tax for is $€ 989$, compared to $€ 775$ for wealth-tax donations. $48 \%$ of the

\footnotetext{
${ }^{43}$ See for example Brown and Taylor (2019).

${ }^{44}$ We use a broad income concepts, summing up all household income components from labor and capital, and before any deduction of the tax base (called the Revenu brut global.
} 
Table 2: Descriptive statistics: Households liable to the wealth tax in 2016

\begin{tabular}{lcccccc} 
& Mean & Std. Dev. & p25 & p50 & p75 & Frac. $>0$ \\
\hline Nb. of fiscal shares & 2.93 & 1.33 & 1.98 & 2.97 & 3.96 \\
Age & 59 & 12 & 50 & 58 & 67 & \\
Income & 135,227 & 271,529 & 52,467 & 86,003 & 143,700 & \\
Total gross wealth & $3,015,480$ & $4,773,810$ & $1,687,549$ & $2,129,593$ & $2,992,436$ \\
Charitable donations (income tax) & 989 & 25421 & 0 & 0 & 427 & 0.48 \\
Political donations (income tax) & 33 & 447 & 0 & 0 & 0 & 0.049 \\
Donation (wealth tax) & 755 & 4,931 & 0 & 0 & 0 & 0.15 \\
\hline
\end{tabular}

Observations

356,227

Notes: The table shows descriptive statistics of the main variables used in the analysis for 2016. The sample consists of all the households liable to the wealth tax on their 2016 wealth. To the exception of the "Nb. of fiscal shares" and the "Age" variables, all the variables are in euros.

households liable to the wealth tax in 2016 declare a charitable donation, a share much higher than when we consider the overall population. While the share of political donors $-4.9 \%-$ may seem small, it is similarly much higher than for the overall population (less than 1\%).

Our treated group is made of the households who left the wealth tax returns following the reform - and who can thus no longer benefit from the $75 \%$ wealth-tax deduction from 2017 onward. Our control group is composed of the households who are liable to the new wealth tax (whose tax schedule is unchanged), and who can still benefit from the $75 \%$ wealth-tax deduction. In Table 3, we compare the characteristics of these two groups before the reform. The control group consists of richer households, who also declare higher givings than the treated group on average.

Table 3: Descriptive statistics: Characteristics of the treated and of the control groups in 2016

\begin{tabular}{lccccc}
\hline & \multicolumn{2}{c}{ Control } & \multicolumn{2}{c}{ Treatment } \\
& Mean & Sd & Mean & Sd & P-value \\
\hline Number of fiscal shares & 3.02 & 1.31 & 2.88 & 1.33 & 0 \\
Age & 58 & 11 & 59 & 12 & 0 \\
Income & 190,891 & 396,342 & 108,112 & 175,725 & 0 \\
Total gross wealth & $4,317,088$ & $7,139,525$ & $2,373,508$ & $2,764,268$ & 0 \\
Charitable donations (income tax) & 1514 & 27,667 & 733 & 24,248 & 0 \\
Political donations (income tax) & 61 & 634 & 20 & 318 & 0 \\
Donation (wealth tax) & 1217 & 6,994 & 527 & 3468 & 0 \\
\hline Number of households & \multicolumn{7}{c}{117,663} & \multicolumn{5}{c}{238,564} \\
\hline
\end{tabular}

Notes: The table shows descriptive statistics for the main variables used in the analysis for 2016 for the two groups. The sample consists of all the households liable to the wealth tax on their 2016 wealth. The control group corresponds to the households who are still liable to the wealth tax in 2017, while the households included in the treated group are not.

More precisely, we estimate the following two equations: 


$$
\begin{aligned}
& \ln (1-\tau)_{i, t}=\pi_{0}+\pi_{1} \text { Treatment }_{i} * \text { Post }_{t}+\mathbf{X}_{\mathbf{i}, \mathbf{t}}^{\prime} \boldsymbol{\pi}_{\mathbf{2}}+\eta_{i}+\gamma_{t}+u_{i t} \\
& \text { political giving } \left._{i, t}=\beta_{0}+\beta_{1} \ln \widehat{(1-\tau)}\right)_{i, t}+\mathbf{X}_{\mathbf{i}, \mathbf{t}}^{\prime} \boldsymbol{\beta}_{\mathbf{2}}+\eta_{i}+\gamma_{t}+u_{i t}
\end{aligned}
$$

where as before $i$ indexes the households and $t$ the years. The time period is 2013-2019 (given we only observe political donations data since 2013). In the first stage (equation (2)), the dependent variable, $\ln (1-\tau)_{i, t}$, is the marginal tax price of charitable giving. Our explanatory variable of interest, Treatment ${ }_{i} *$ Post $_{t}$, is the interaction between an indicator variable equal to one for the households liable to wealth tax in 2016 but who leave the wealth tax in 2017, and to 0 for households liable to wealth tax in 2016 and who pay the new tax on housing assets in 2017, and an indicator variable equal to one for the years following the reform (2017-2019). We control for household and year fixed effects (respectively $\eta_{i}$ and $\gamma_{t}$ ), i.e. rely for identification on within-household variations.

$\mathbf{X}_{\mathbf{i}, \mathbf{t}}^{\prime}$ is a vector of household-level controls, including the number fiscal shares, the age, 10 -splines in income, the average gross wealth for 2013-2016, and the average wealth-tax donations for 2013-2016. We cluster the standard errors at the household level.

In the second stage (equation (3)), we investigate how the instrumented price of charitable giving $\left.(\ln \widehat{(1-\tau})_{i, t}\right)$ affects political giving (political giving ${ }_{i, t}$ ). Given political donations are equal to zero for a number of households, we use the inverse hyperbolic sine transformation of the dependent variable in our preferred specification. ${ }^{45}$

Our identification assumption is the following: the 2018 wealth-tax reform only affected political donations through its effect on the marginal tax price of charitable giving. This assumption sounds reasonable given political giving was not eligible to wealth tax deductions, and so not directly affected by the reform.

Discussion Given that what we are ultimately willing to estimate is the relationship between charitable and political giving (as in equation (1)), one might be surprised by the fact that in the second stage we instrument the tax price of charitable donations $\left(\ln (1-\tau)_{i, t}\right)$ rather than the charitable donations themselves, as in Yörük (2015). We decided to do so for the following reason: if we were to instrument charitable donations, we would need to assume that the tax price of giving is uncorrelated with the unobservable covariates which might affect political giving. While this assumption sounds reasonable in the U.S. context considered by Yörük (2015), it does not hold in the French one given political donations also benefit from tax deductions.

The identification assumption needed here is much weaker given we only need to assume

\footnotetext{
${ }^{45}$ In the robustness section 5.1 , we show that our results are robust to rather using the logarithm of the dependent variable plus one.
} 
that the 2018 wealth-tax reform only affected political donations through its effect on the marginal tax price of charitable giving. While this assumption sounds reasonable, it might be violated if, because of the wealth-tax gains produced by the reform - i.e. of the increased resources available for the households as a result - the households decided to give more. Note however that such an effect would lead us to underestimate the impact of the tax reform (that acts as a negative shock on the price of giving) and so that our estimates should be considered as lower-bound effects.

To alleviate this concern, we compute the wealth tax gain each household got out from the reform (both treated and control households may have enjoyed a positive income shock thanks to the change in the taxable base, given control households no longer pay the wealth tax on their financial assets since 2018). This allows us first to introduce this variable as a control, and second, to reduce our sample of analysis to treated and control groups who enjoyed a similar wealth-tax gain following the reform. The wealth-tax gain is computed as the difference between the observed wealth tax due in 2016 and the wealth tax due in 2017.46

Figure 4 plots the distribution of the wealth tax gain due to the 2018 wealth-tax reform both for the treated and control households. On average, households liable to wealth tax in 2016 benefited from a $€ 8,803$ decrease if their wealth tax (€10,598 in the control group, $€ 7,918$ in the treated group). Interestingly for us, we have a lot of treated and control households who face a similar tax gain following the reform. Hence, comparing these two sets of households, we are able to alleviate the bias that might come from an income effect.

\section{Empirical results}

In this section, we report the results of our estimations. We first present the first and second stage estimates, before discussing the heterogeneity of our effects. We then investigate whether our effects mostly happen at the intensive or at the extensive margin.

\subsection{First stage estimates}

Table 4 reports the results of the first stage. Column (1) only controls for year fixed effects, in Column (2) we add the households fixed effects, and the full set of controls in Columns

\footnotetext{
${ }^{46}$ Ideally, we would like to use the asset distribution of each household in 2016 - i.e. before the reform between financial and real-estate assets, so that to compute the tax gain we would have observed if the reform had happened one year before. One may indeed be concerned by the fact that households might have partly consumed their wealth - or increase their propensity to avoid tax - following the reform (note however that this is very unlikely, given the reform only decreased the taxable base, with no change in the tax schedule). The difficulty comes from the fact that the asset composition is only known for the subset of the households who own more than $€ 2.5$ million (i.e. around $25 \%$ of the households). Households who own between $€ 1.3$ and $€ 2.5$ millions indeed only have to report their overall wealth. Reassuringly, in the online Appendix Section A.1, we show that for the subset of the households for which we have information on the asset distribution, these two figures are strongly correlated.
} 
Figure 4: Distribution of the amount of the wealth tax due change at the removal of the wealth tax

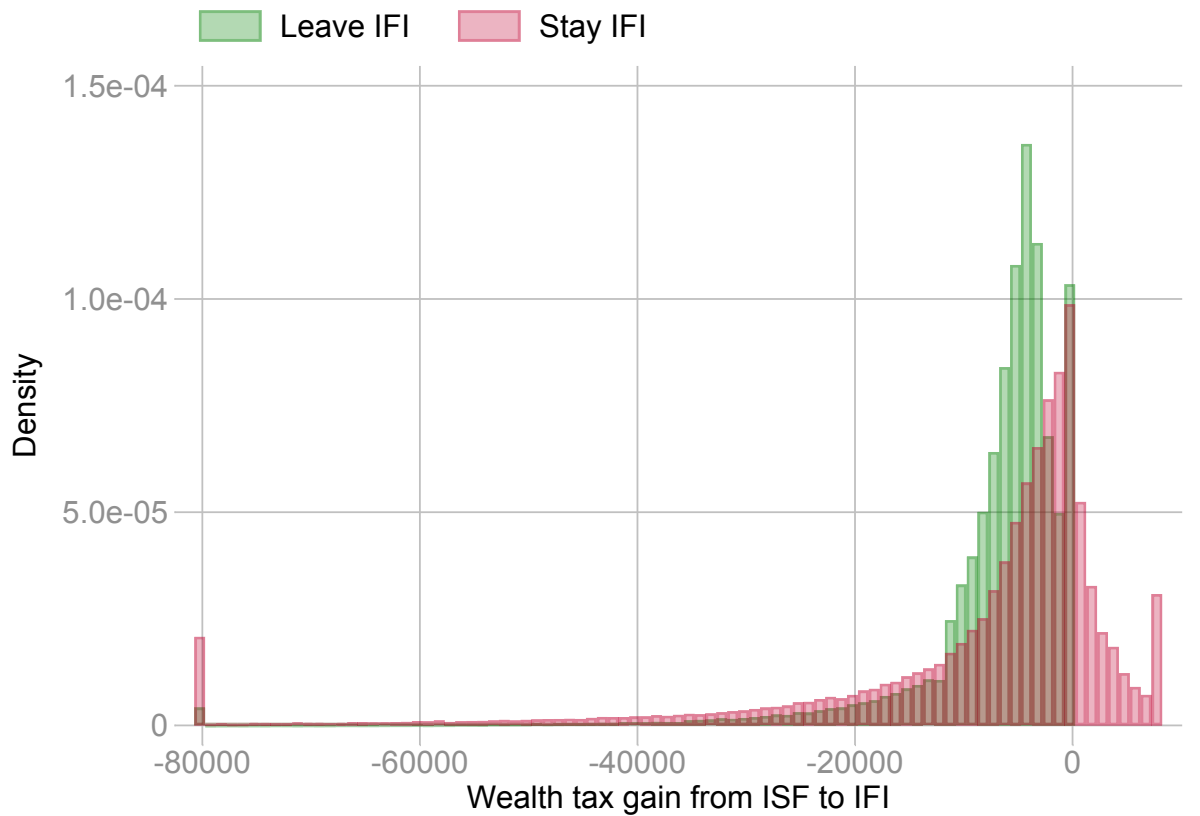

Notes: The Figure plots the distribution of the change in wealth tax liability at the household-level at the removal of the wealth $\operatorname{tax}(2017$ vs. 2016 wealth) for all households liable to the wealth tax on their 2016 wealth. Households still liable to the wealth tax in 2017 are in red while the ones who are not liable anymore are in green. A negative number means that the amount of tax due decreased following the reform. 
Table 4: First-stage estimation: The impact of the 2018 wealth-tax reform on the marginal tax price of charitable donations

\begin{tabular}{lccc}
\hline \hline & $(1)$ & $(2)$ & $(3)$ \\
\hline Treated household & $0.1677^{* * *}$ & $0.1678^{* * *}$ & $0.1662^{* * *}$ \\
$\times$ Post-reform years & $(0.0004)$ & $(0.0004)$ & $(0.0004)$ \\
\hline Controls & No & No & Yes \\
Year FE & Yes & Yes & Yes \\
Households FE & No & Yes & Yes \\
Adjusted R-sq & 0.90 & 0.92 & 0.93 \\
Observations & $2,344,567$ & $2,342,827$ & $2,342,677$ \\
Cluster(households) & 354,326 & 352,586 & 352,572 \\
Mean of dep. var. & -1.248 & -1.248 & -1.248 \\
Std. dev of dep. var. & 0.168 & 0.168 & 0.168 \\
\hline \hline
\end{tabular}

Notes: ${ }^{*} \mathrm{p}<0.10,{ }^{* *} \mathrm{p}<0.05,{ }^{* * *} \mathrm{p}<0.01$. The time period is 2013-2019. Models are estimated using an OLS (standard errors clustered at the household level between parentheses). An observation is a household-year. The dependent variable is the logarithm of the marginal tax price of charitable donations. The vector of controls includes the number fiscal shares, the age, 10-splines in income, the average gross wealth for 20132016, and the average wealth-tax donations for 2013-2016. All specifications control for year fixed effects, and Columns (2) and (3) also include household fixed effects.

(3). We show that the tax reform led to an increase in the marginal price of charitable giving for the treated group by around $16.6 \%$. The magnitude of the effect nearly does not change depending on the specifications. Further, note that the R-squares are always above 0.9.

Before turning to the second stage, we report the reduced-form estimations in Table 5. The dependent variable is the (inverse hyperbolic sine transformation) of the total amount of political donations made by household $i$ in year $t$. As before, we include year fixed effects in Column (1), add the household fixed effects in Column (2) and finally the full set of controls in Column (3). We obtain a 4.2 to $4.7 \%$ increase in political donations for the treated group compared to the control group following the reform. This impact is statistically significant at the one percent level.

These reduced-form estimates point toward a substitution effect between charitable and political giving.

\subsection{Second stage}

Table 6 presents the results of the second stage estimates. In the first three columns, for the sake of comparison, we report the OLS estimates; the second-stage coefficients are presented in Columns (4) to (6). We find that a one-percent increase in the price of charitable giving leads to a 23.4 to $25.5 \%$ increase in political donations; these estimates are statistically significant at the one-percent level. In other words, political and charitable donations seem to be substitute. This result is consistent with Petrova et al. (2020) who deduce substituability from the fact that households react differently to natural disasters and to political ads in their 
Table 5: Reduced-form estimation: The impact of the 2018 wealth-tax reform on political donations

\begin{tabular}{lccc}
\hline \hline & $(1)$ & $(2)$ & $(3)$ \\
\hline Treated household & $0.0465^{* * *}$ & $0.0427^{* * *}$ & $0.0422^{* * *}$ \\
$\times$ Post-reform years & $(0.0034)$ & $(0.0034)$ & $(0.0033)$ \\
\hline Controls & No & No & Yes \\
Year FE & Yes & Yes & Yes \\
Households FE & No & Yes & Yes \\
Within R-sq & 0.00 & 0.00 & 0.00 \\
Observations & $2,344,567$ & $2,342,827$ & $2,342,677$ \\
Cluster(households) & 354,326 & 352,586 & 352,572 \\
Mean of dep. var. & 0.262 & 0.262 & 0.262 \\
Std. dev of dep. var. & 1.241 & 1.241 & 1.241 \\
\hline \hline
\end{tabular}

Notes: ${ }^{*} \mathrm{p}<0.10,{ }^{* *} \mathrm{p}<0.05,{ }^{* * *} \mathrm{p}<0.01$. The time period is 2013-2019. Models are estimated using an OLS (standard errors clustered at the household level between parentheses). An observation is a household-year. The dependent variable is the inverse hyperbolic sine transformation of the total amount of political donations. The vector of controls includes the number fiscal shares, the age, 10-splines in income, the average gross wealth for 2013-2016, and the average wealth-tax donations for 2013-2016. All specifications control for year fixed effects, and Columns (2) and (3) also include household fixed effects.

giving behavior. ${ }^{47}$

\subsection{Taking into account the potential income effect}

As we have highlighted above, our estimates might be biased if the positive "income effect" due to the wealth-tax reform led to an increase in political donations, i.e. if, due to the fact that thanks to the reform households have more cash at their disposal, they decide to contribute more.

To alleviate this concern, we first control for the wealth-tax gains. As appears clearly in Column (6) of Table 6, doing so only very slightly decreases our estimated cross-price elasticity (from 25.4 to $23.9 \%$ ).

Second, we reduce our sample of analysis to "similar" treated and control households with respect to the tax gain they got out from the reform. Despite the lower number of observations (283, 379 households included compared to 352,586 until now), doing so yields similar insights, with an estimated coefficient slightly below our main result (19.8\%), as appears in the online Appendix Table E.3.

\subsection{Heterogeneity of the effects}

Until now, we have shown that there is substituability between charitable and political donations, with a 10 to $14 \%$ cross elasticity. In this section, we consider a number of dimensions

\footnotetext{
${ }^{47}$ However, our findings contradict Yörük (2015) who documents complementarity between charitable and political giving. We will come back to this point in the discussion section 5.2 below.
} 
Table 6: Second-stage estimation: The impact of the instrumented price of charitable donations on political donations

\begin{tabular}{lcccccc}
\hline Dependent variable & \multicolumn{7}{c}{ ihs political donations } \\
& \multicolumn{7}{c}{ OLS } & $(2)$ & $(3)$ & $(4)$ & $(5)$ & $(6)$ \\
\hline $\ln \left(1-\tau \_i, t\right)$ & 0.009 & $0.017^{* *}$ & $0.034^{* * *}$ & $0.255^{* * *}$ & $0.254^{* * *}$ & $0.239^{* * *}$ \\
& $(0.007)$ & $(0.007)$ & $(0.008)$ & $(0.020)$ & $(0.020)$ & $(0.019)$ \\
& & & & & & \\
\hline Controls & No & Yes & Yes & No & Yes & Yes \\
Wealth tax gain & No & No & Yes & No & No & Yes \\
Year FE & Yes & Yes & Yes & Yes & Yes & Yes \\
Households FE & Yes & Yes & Yes & Yes & Yes & Yes \\
Observations & $2.34 \mathrm{e}+06$ & $2.34 \mathrm{e}+06$ & $2.26 \mathrm{e}+06$ & $2.34 \mathrm{e}+06$ & $2.34 \mathrm{e}+06$ & $2.26 \mathrm{e}+06$ \\
Cluster(households $)$ & 352,586 & 352,572 & 352,540 & 352,586 & 352,572 & 352,540 \\
Mean of dep. var. & 0.262 & 0.262 & 0.261 & 0.262 & 0.262 & 0.261 \\
Std. dev of dep. var. & 1.241 & 1.241 & 1.239 & 1.241 & 1.241 & 1.239 \\
\hline \multicolumn{1}{c}{ Standard errors in parenthesis. ${ }^{*} \mathrm{p}<0.10, * * \mathrm{p}<0.05, * * * \mathrm{p}<0.01}$. & & & &
\end{tabular}

Notes: $* \mathrm{p}<0.10,{ }^{* *} \mathrm{p}<0.05,{ }^{* * *} \mathrm{p}<0.01$. The time period is 2013-2019. Models are estimated using an OLS (standard errors clustered at the household level between parentheses). An observation is an household-year. The vector of controls includes the number fiscal shares, the age, 10-splines in income, the average gross wealth for 2013-2016, and the average wealth-tax donations for 2013-2016. All specifications control for year and households fixed effects.

of heterogeneity that we present in turn. For each dimension, we report the point estimates corresponding to our most demanding specification (with year and household fixed effects, as well as the full set of controls, as in Column (4) of Table 6).

First, we investigate whether the magnitude of the results varies depending on the wealth of the households. To do so, we split our sample of households into five quintiles depending on their 2016 wealth. Figure 5a reports the results: the magnitude of the effect is higher for the households in the upper wealth quintile compared to the households in the first four quintiles for which it is relatively similar. The fact that the effect is stronger for the households whose wealth was higher before the reform is not surprising given that, for a given donation, those households were more likely to benefit from the wealth-tax deduction (given that to benefit from the tax deduction, the latter needs to be lower than the wealth-tax due). Consistently with this finding, we show in Figure $5 b$ that the magnitude of the effect is much larger for the households who benefited from a wealth-tax deductions in 2016 than for those who did not.

Next, in Figure 5c, we perform the estimation separately depending on the 2016 income. Just as for wealth, we separate the households into five income quintiles. We find that the magnitude of the effect is statistically significantly higher for the households in the fifth income quintile. 
Figure 5: Heterogeneity of the effects

(a) Depending on wealth

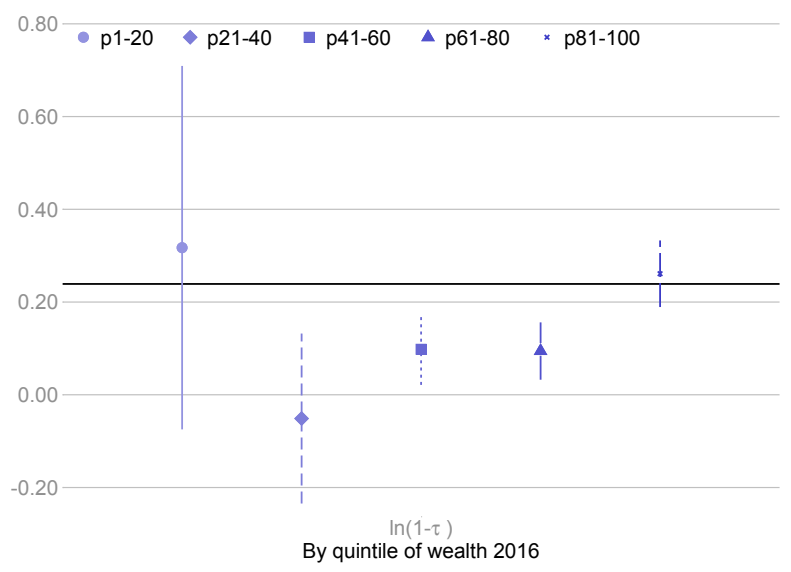

(b) Depending on wealth-tax deduction

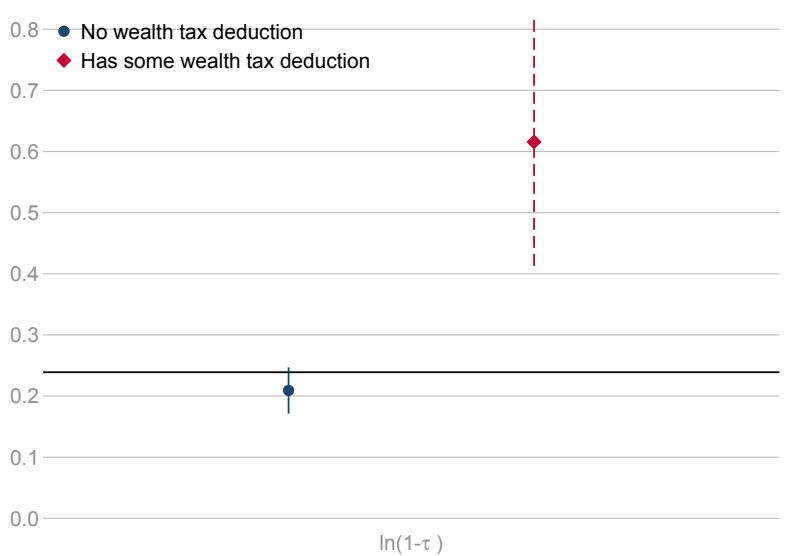

(c) Depending on income

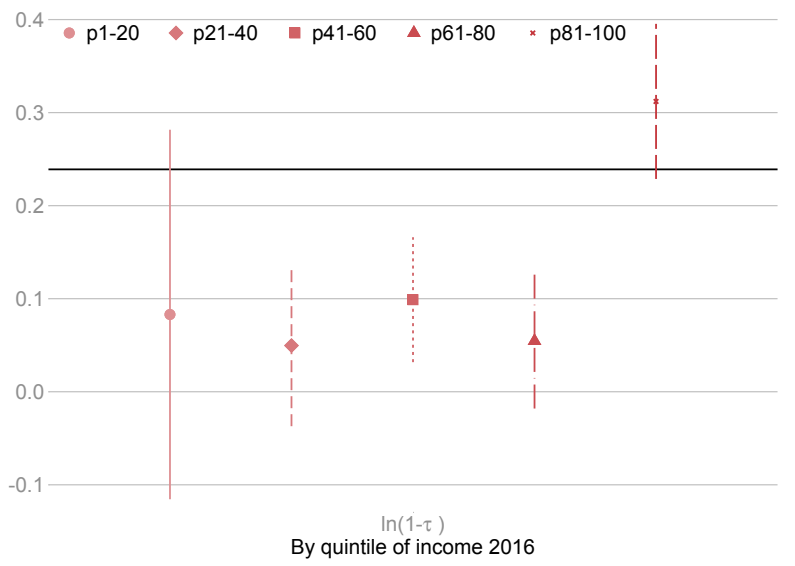

Notes: The Figure reports the coefficient and $95 \%$ confidence interval we obtain when estimating equation (3) with year and household fixed effects as well as the full set of controls (specification similar to the one reported in Column (4) of Table 6). Panel (a) shows the estimation of this coefficient separately for the households in our sample depending of their quintile of wealth in 2016. In Panel (b), we perform the estimation separately depending on whether the households benefited from a wealth-tax deduction for charitable givings in 2016. Finally, in Panel (c), we estimate the effect separately depending on the 2016 income. 


\subsection{Disentangling between the extensive and the intensive margin}

Heretofore, we have considered the overall relationship between political giving and the marginal price of charitable donations. Our effect may happen at the extensive and/or at the intensive margin. We consider these two margins separately in this section.

The probability of giving First, we investigate whether a change in the marginal price of charitable donations affects the probability of making a political donations. To do so, we estimate a model similar to the one presented in equation (3), but where the dependent

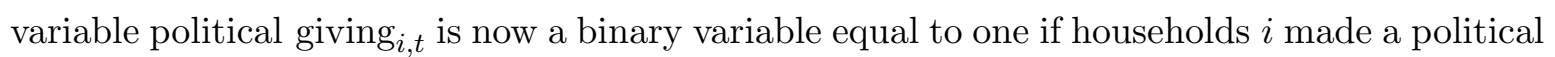
donation in year $t$ and to zero otherwise.

We use a linear probability model. Table D.1 reports the results of the second stage estimates. In the first three columns, we report the OLS estimates; the second-stage coefficients are presented in Columns (4) to (6). We find that a one-percent increase in the price of charitable giving leads to a 3.3 to $3.7 \%$ increase in the probability to make a political donation; these estimates are statistically significant at the one-percent level. These results are also consistent with some substituability happening at the extensive margin of the giving behaviour.

\section{Discussion and Robustness checks}

\subsection{Robustness check}

We perform several robustness checks. This section briefly describes them; the detailed results for these tests are available in the online Appendix Section E.

First-euro price Until now, we have considered the marginal tax price of donations. We show that our results are robust to rather using the first-euro price. ${ }^{48}$ Table E.1 shows the regression results using the first-euro price instead of the marginal price. The estimated coefficients are qualitatively similar although of a lower magnitude (12.9\% instead of $25.5 \%)$.

Logarithm Given political donations are equal to zero for a number of households, we use the inverse hyperbolic sine transformation of the dependent variable in our preferred specification. In the online Appendix Table E.2, we show that our results are robust to rather using the logarithm of the donations plus 1 .

\footnotetext{
${ }^{48}$ Bakija and Heim (2011) use the first-dollar price as an instrument for the actual price of a donation; see also Fack and Landais (2010)
} 
Sample Finally, we show that our results are robust to a number of sample changes. First, we show that they do not vary if we consider a balanced panel, i.e. only include the households that we observe for each year during our entire time period (online Appendix Table E.4). Second, we show that our results are robust to dropping 2017; 2017 was indeed an electoral year in France (with both the Presidential and the legislative elections), and so might be specific in terms of political donations (online Appendix Table E.5). Further, one might be worried by the fact that 2017 was also the year of the announcement of the wealth-tax reform (in December 2017). Third, we show that our findings do not vary if we drop the year 2016 and rather use 2015 as a reference point (online Appendix Table E.6). Candidates raise fund a number of months in advance of the election, and we observe a large increase in political donations in 2016 for top-income earners (Cagé, 2018).

\subsection{Politically motivated donations to charities}

In this article, we have shown evidence of substituability between charitable and political donations: when there is an increase in the tax price of charitable giving - i.e. in the tax incentives faced by the households to make charitable donations - we observe an increase in political donations. One possible interpretation for this substituability between charitable and political giving is the fact that charitable donations may be at least partially driven by political motivations (see e.g. Bertrand et al., 2020a).

\section{What is the purpose of the charitable organizations, and how much do they} receive? In France, as we have highlighted in the background section 2.1.2, only the nonprofit organizations recognized as "being of public utility" (the so-called FRUPs) and the non-profit research, higher education or artistic institutions of general interest can benefit from the wealth-tax deductions. This category includes politically-involved think-tanks such as the "Fondation Jean Jaurès" on the left and the "Fondation pour la recherche sur les administrations et les politiques publiques" (iFRAP) on the right, i.e. nonprofit organizations whose purpose is clearly at least partly political.

We have collected the list of the FRUPs in France during our period of interest. For each of these FRUPs, we have their name as well as their purpose (e.g. for the iFRAP: "the purpose of the iFRAP Foundation is to carry out scientific studies and research on the effectiveness of public policies, particularly those aimed at achieving full employment and economic development, to make the results of these studies known to public opinion, to propose measures for improvement and to carry out all actions with a view to the implementation of the proposed measures by the Government and Parliament" ${ }^{49}$ ). Relying on natural language

\footnotetext{
49 "La Fondation iFRAP a pour but d'effectuer des études et des recherches scientifiques sur l'efficacité des politiques publiques, notamment celles visant la recherche du plein emploi et le développement économique, de faire connaître le fruit de ces études à l'opinion publique, de proposer des mesures d'amélioration et de mener
} 
processing methods, we recover the broad category of each of the FRUPs, e.g. sports, culture, politics, etc. The precise methodology is described in the online appendix.

Next, for all the FRUPs for which this information is available ${ }^{50}$, we rely on their financial accounts to study the evolution of the donations they receive. For now, we have this information for 38 different FRUPs, including the donations received, as well as the operating expenses and revenues. ${ }^{51}$ Online Appendix Figure C.9 plots the evolution of the donations received by these FRUPs. While for now we only have collected data for around $5 \%$ of the FRUPs, the donations they receive amount to nearly $€ 100$ millions, i.e. a very large share of the total donations made in France.

Political considerations driving donations to non-political charities Finally, note that even donations to non-political charities can be driven by political considerations. ${ }^{52}$ E.g. if donations are used by large donors as a way to substitute for the State, for instance if one believes that successful entrepreneurs are more efficient than the State at allocating resources for public goods such as health or education. In a country like France as of today - even if philanthropy is much less developed than in the U.S. - the main contemporary art collections are exposed in museums owned by billionaires such a François Pinault (who opened in 2021 a private museum in a former 18th-century grain exchange near Les Halles in central Paris ${ }^{53}$ ) or Bernard Arnault (who opened the Louis Vuitton Foundation in 2017). While Arnault benefited from very large tax deductions for the funding of his foundation, these museums enter as of today in direct competition with public institutions, which, some argue, are weakened by this competition. As highlighted for example in the "Art Newspaper", the rise of these private museums partly happened "to the detriment of [public] museums such as the Grand Palais, Orsay, the Louvre and Pompidou". ${ }^{54}$ The newspaper compared the cost of the Chtchoukine exposition in the Vuitton Foudation in $2017-€ 13$ millions - with the average cost of an important exposition in a public museum - $€ 2.5$ million.

Further, these foundations can be used by the donors as a way to promote their companies. Bernard Arnault's museum, the Louis Vuitton Foundation, is named after the billionaire's main brand; as highlighted by the "Cour des Comptes" (Court of Accounts, i.e. the government institution that performs financial audit ${ }^{55}$ ), this museum "constitutes a case,

toutes les actions en vue de la mise en œuvre par le Gouvernement et le Parlement des mesures proposées."

${ }^{50}$ When the information is available, it is published on the website of the "Journal Officiel" from which we scrapped all the accounts.

${ }^{51}$ The panel of FRUPs is unbalanced given some of them entered or exited during our time period. We are still in the process of collecting these, hence the relatively low number of FRUPs included for now.

${ }^{52}$ Using French data on public subsidies to nonprofit, Urvoy (2020) has shown that politicians partly allocate governmental transfers to nonprofit organizations to improve their electoral prospects.

${ }^{53}$ The Bourse de Commerce-Pinault Collection is a 10,500 square meter museum. Pinault - whose wealth is estimated to $\$ 53.6$ billion -'s collection contains around 10,000 works by nearly 400 artists.

${ }^{54}$ https://www.artnewspaper.fr/feature/public-prive-de-la-concurrence-a-l-ecosysteme

${ }^{55}$ Statutory audit on the executive branch of power. 
exceptional in its scope, of using the possibilities offered by the tax legislation in terms of patronage in order to develop an ambitious cultural project while ensuring the promotion of the main brand of a group, in a logic of corporate communication that articulates contemporary art, fashion and luxury." 56 Similarly, the President of the Centre Georges-Pompidou museum, Serge Lasvignes, said in 2017 about the Pinault foundation: "it is about showing contemporary art from the collection of François Pinault. Some will say that there will be an echo between his way of exhibiting and his commercial activities" 57 (on the disproportionate power of François Pinault on the art market and the benefits he can get from it through the auction house Christie's he owns see Vivant, 2009). An increasing number of observers similarly question the growing funding of higher education by philanthropy in France (see e.g. Chambard, 2020). ${ }^{58}$

Furthermore, charitable donations can be a way for a large donors to open a few doors. E.g. for a donor, sitting on the board of directors of a foundation and/or participating in the various events organized by this foundation can allow her to expand her social capital (see e.g. Depecker et al. (2018) and Monier (2019) for recent work, and Ostrower (1997) for a seminal study). It can be seen as an "investment". ${ }^{59}$ In other words, to paraphrase McGoey (2015) whose focus is on the Gates foundation, there is - at least when one considers large donors (which is the case here given our identification relies on donors who wee and/or are still eligible to the wealth tax) there is "no such thing as a free gift". As quantified in the economic literature by Bertrand et al. (2020a), 16.1\% of total U.S. corporate charitable giving can be interpreted as politically motivated. The evidence provided here shows that charitable giving by individuals is similarly also partly politically motivated. ${ }^{60}$

Welfare implications and policy relevance Should we consider the fact that we find substituability between political and charitable giving as a good news or a bad news? What are the welfare consequences, and what should be the policy implications?

In France as well as in a number of other countries (Italy, Spain, Belgium, etc.), campaign finance laws place limits on political donations, but no cap on charitable giving. Yet, our findings pointing to political motivations behind charitable giving challenge such a choice.

\footnotetext{
56 "Constitue un cas, exceptionnel par son ampleur, d'utilisation des possibilités offertes par la législation fiscale en matière de mécénat afin de développer un projet culture ambitieux tout en assurant la promotion de la marque principale d'un groupe, dans une logique de communication d'entreprise qui articule art contemporain, mode et luxe". Cited in Cagé (2020).

57 "Il s'agit de montrer l'art contemporain à partir de la collection de François Pinault. Certains diront qu'il y aura écho entre sa façon d'exposer et ses activités commerciales." (https://www.parismatch.com/Culture/Art/Le-centre-Pompidou-a-40-ans-Son-ADN-c-est-la-thematique1175552).

${ }^{58}$ Note however that this is not a new phenomena. See e.g. Durand (2016).

${ }^{59}$ See also Bertrand et al. (2020b) on political giving as a way for donors to invest in influence.

${ }^{60}$ See also Bertrand et al. (2018) who provide evidence that corporate foundations' charitable grants reach targeted non-profits just before those same non-profits engage in public commentary.
} 
For a politically-motivated donor who faces a cap for her political donations, giving to a think tank can indeed be a relatively easy alternative. Further, it also questions the relevance of having tax policies for charitable giving that are much more generous than for political donations (which is the case in a large number of countries).

\subsection{External validity}

In this paper, we rely on the use of French data. While one might question the external validity of our findings, we think on the contrary that the case of France is of particular interest for many reasons, and can have important policy implications for other countries. First, France has a tax credit rate that is among the highest in Western democracies. While, as highlighted in the introduction, tax policies in many countries increasingly offer substantial incentives to donate to charities, we think it is of particular importance to investigate the relevance of such policies in a country where the deductions are particularly high.

Second in France, there are tax deductions not only for charitable contributions but also for political donations, unlike in the U.S.. Yet many other countries, among which Germany, Italy and Spain ${ }^{61}$ also have such deductions (see Cagé, 2018). Thanks to the unique data we have for France, we can study the efficiency of these deductions, which, to the extent of our knowledge, has never been done until now (and could not be done with U.S. data).

\section{Conclusion}

This paper uses a reform of the wealth tax that decreased the tax price for charitable contributions in France to evidence the substituability of these contributions with political donations. More precisely, the reform restricted the definition of the wealth tax base to real-estate assets excluding the financial assets which were previously included. We rely on a new panel dataset including all the households filling their income tax and/or their wealth tax returns in France between 2006 and 2019. We focus on the sample of households liable to the wealth tax in 2016 and use the panel dimension of the data to follow these households over time and across taxes. We show that political and charitable giving are substitute. A one-percent increase in the price of charitable giving leads to a 19 to $25 \%$ increase in political donations. We also study the heterogeneity of this cross-tax price elasticity among the distribution of wealth. The magnitude of the effect are particularly strong among the top $20 \%$ of the wealth taxpayers.

Our findings suggest that philanthropy may be at least partly politically motivated. This idea is support by foundation-level data: for all the nonprofit organizations that are recognized as "being of public utility" and that can benefit from the wealth-tax deduction, we collect data on the donations they receive and classify them depending on their purpose, separating

\footnotetext{
${ }^{61}$ It was also the case in Belgium between 1985 and 1993.
} 
in particular foundations that are politically involved from those that are not. Our findings have important implications for the optimal regulation of tax incentives. 


\section{References}

Aghion, P., Ciornohuz, V., Gravoueille, M., and Stantcheva, S. (2019). Reforms and Dynamics of Income Evidence Using New Panel Data. Working paper.

Almunia, M., Guceri, I., Lockwood, B., and Scharf, K. (2020). More giving or more givers? The effects of tax incentives on charitable donations in the UK. Journal of Public Economics, 183:104114.

Andreoni, J. (1989). Giving with Impure Altruism: Applications to Charity and Ricardian Equivalence. Journal of Political Economy, 97(6):pp. 1447-1458.

Andreoni, J. (1990). Impure Altruism and Donations to Public Goods: A Theory of WarmGlow Giving. The Economic Journal, 100(401):pp. 464-477.

Andreoni, J. and Payne, A. A. (2013). Charitable Giving. In Auerbach, A. J., Chetty, R., Feldstein, M., and Saez, E., editors, Handbook of Public Economics, volume 5 of Handbook of Public Economics, pages 1-50. Elsevier.

Andreoni, J., Rao, J. M., and Trachtman, H. (2017). Avoiding the Ask: A Field Experiment on Altruism, Empathy, and Charitable Giving. Journal of Political Economy, 125(3):625653.

Ansolabehere, S., de Figueiredo, J. M., and Snyder, J. M. J. (2003). Why is There so Little Money in U.S. Politics? Journal of Economic Perspectives, 17(1):105-130.

Backus, P. and Grant, N. (2016). Consistent Estimation of the Tax-Price Elasticity of Charitable Giving with Survey Data. Technical report.

Bakija, J. (2013). Tax Policy and Philanthropy: A Primer on the Empirical Evidence for the United States and Its Implications. Social Research, 80(2):557-584.

Bakija, J. and Heim, B. (2008). How Does Charitable Giving Respond to Incentives and Income? Dynamic Panel Estimates Accounting for Predictable Changes in Taxation. NBER Working Papers 14237, National Bureau of Economic Research, Inc.

Bakija, J. and Heim, B. T. (2011). How Does Charitable Giving Respond to Incentives and Income? New Estimates From Panel Data. National Tax Journal, 64(2):615-650.

Barber, M. J. (2016). Ideological Donors, Contribution Limits, and the Polarization of American Legislatures. The Journal of Politics, 78(1):296-310.

Bekkouche, Y., Cagé, J., and Dewitte, E. (2020). The Heterogeneous Price of a Vote: Evidence from Multiparty Systems, 1993-2017. CEPR Discussion Papers 15150, C.E.P.R. Discussion Papers.

Bertrand, M., Bombardini, M., Fisman, R., Hackinen, B., and Trebbi, F. (2018). Hall of Mirrors: Corporate Philanthropy and Strategic Advocacy. NBER Working Papers 25329, National Bureau of Economic Research, Inc.

Bertrand, M., Bombardini, M., Fisman, R., and Trebbi, F. (2020a). Tax-Exempt Lobbying: Corporate Philanthropy as a Tool for Political Influence. American Economic Review, 
110(7):2065-2102.

Bertrand, M., Bombardini, M., Fisman, R., Trebbi, F., and Yegen, E. (2020b). Investing in influence: Investors, portfolio firms, and political giving. Working paper.

Bombardini, M. and Trebbi, F. (2020). Empirical Models of Lobbying. Annual Review of Economics, 12(1):391-413.

Brown, E. and Lankford, H. (1992). Gifts of money and gifts of time estimating the effects of tax prices and available time. Journal of Public Economics, 47(3):321-341.

Brown, S. and Taylor, K. (2019). Charitable Behaviour and Political Ideology: Evidence for the UK. Working Papers 2019002, The University of Sheffield, Department of Economics.

Brülhart, M., Gruber, J., Krapf, M., and Schmidheiny, K. (2016). Taxing Wealth: Evidence from Switzerland. Working Paper 22376, National Bureau of Economic Research.

Cagé, J. (2018). Le prix de la démocratie. Fayard (English version: The Price of Democracy, Harvard University Press, 2020).

Cagé, J. (2020). Libres et égaux en voix. Fayard.

Chambard, O. (2020). Business Model: l'université, nouveau laboratoire de l'idéologie entrepreneuriale. Collection Laboratoire des sciences sociales. La Découverte.

Chamon, M. and Kaplan, E. (2013). The Iceberg Theory of Campaign Contributions: Political Threats and Interest Group Behavior. American Economic Journal: Economic Policy, $5(1): 1-31$.

Dawood, Y. (2015). Campaign Finance and American Democracy. Annual Review of Political Science, 18(1):329-348.

DellaVigna, S., List, J. A., and Malmendier, U. (2012). Testing for Altruism and Social Pressure in Charitable Giving. The Quarterly Journal of Economics, 127(1):1-56.

Depecker, T., Déplaude, M.-O., and Larchet, N. (2018). La philanthropie comme investissement. Contribution à l'étude des stratégies de reproduction et de légitimation des élites économiques. Politix, 121(1):9-27.

Deryugina, T. and Marx, B. M. (2020). Is the Supply of Charitable Donations Fixed? Evidence from Deadly Tornadoes. Working Paper 27078, National Bureau of Economic Research.

Doerrenberg, P., Peichl, A., and Siegloch, S. (2017). The elasticity of taxable income in the presence of deduction possibilities. Journal of Public Economics, 151:41-55.

Duquette, N. J. (2016). Do tax incentives affect charitable contributions? Evidence from public charities' reported revenues. Journal of Public Economics, 137:51-69.

Durand, A. (2016). L'odeur de l'argent. Dons et legs dans le financement de l'Université de Paris (1885-années 1930). Revue d'histoire moderne $\& 3$ contemporaine, 63-3(3):64-87.

Fack, G. and Landais, C. (2010). Are Tax Incentives for Charitable Giving Efficient? Evidence from France. American Economic Journal: Economic Policy, 2(2):117-141. 
Fack, G. and Landais, C., editors (2016a). Charitable Giving and Tax Policy: A Historical and Comparative Perspective. Number 9780198723660 in OUP Catalogue. Oxford University Press.

Fack, G. and Landais, C. (2016b). The effect of tax enforcement on tax elasticities: Evidence from charitable contributions in France. Journal of Public Economics, 133:23-40.

Fack, G., Landais, C., and Myczkowski, A. (2018). Biens publics, charité privée: Comment l'État peut-il réguler le charity business? Editions Rue d'Ulm.

Feldstein, M. and Taylor, A. (1976). The Income Tax and Charitable Contributions. Econometrica, 44(6):1201-1222.

Fioretti, M. (2020). Caring or Pretending to Care? Social Impact, Firms' Objectives and Welfare. Working paper.

Fong, C. M. and Luttmer, E. F. P. (2009). What Determines Giving to Hurricane Katrina Victims? Experimental Evidence on Racial Group Loyalty. American Economic Journal: Applied Economics, 1(2):64-87.

Gimpel, J. G., Lee, F. E., and Pearson-Merkowitz, S. (2008). The Check Is in the Mail: Interdistrict Funding Flows in Congressional Elections. American Journal of Political Science, $52(2): 373-394$.

Gordon, S. C., Hafer, C., and Landa, D. (2007). Consumption or Investment? On Motivations for Political Giving. The Journal of Politics, 69(4):1057-1072.

Green, D. P., Krasno, J. S., Panagopoulos, C., Farrer, B., and Schwam-Baird, M. (2015). Encouraging Small Donor Contributions: A Field Experiment Testing the Effects of Nonpartisan Messages. Journal of Experimental Political Science, 2(2):183-191.

Grossman, G. M. and Helpman, E. (1994). Protection for Sale. American Economic Review, 84(4):833-850.

Grossman, G. M. and Helpman, E. (1996). Electoral Competition and Special Interest Politics. The Review of Economic Studies, 63(2):265-286.

Guillot, M. (2019). Who Paid the 75and Incidence in France. Working paper.

Hungerman, D., Rinz, K., Weninger, T., and Yoon, C. (2018). Political campaigns and church contributions. Journal of Economic Behavior and Organization, 155:403-426.

Jakobsen, K., Jakobsen, K., Kleven, H., and Zucman, G. (2019). Wealth Taxation and Wealth Accumulation: Theory and Evidence From Denmark. The Quarterly Journal of Economics, 135(1):329-388.

McGoey, L. (2015). No Such Thing as a Free Gift: The Gates Foundation and the Price of Philanthropy. Verso Books.

Monier, A. (2019). Nos chers Amis américains. Hors collection. Presses Universitaires de France.

Ostrower, F. (1997). Why the Wealthy Give: The Culture of Elite Philanthropy. Princeton 
University Press.

Petrova, M., Perez-Truglia, R., Simonov, A., and Yildirim, P. (2020). Are Political and Charitable Giving Substitutes? Evidence from the United States. Working Paper 26616, National Bureau of Economic Research.

Poole, K. T. and Romer, T. (1985). Patterns of political action committee contributions to the 1980 campaigns for the United States House of Representatives. Public Choice, 47(1):63-111.

Randolph, W. C. (1995). Dynamic Income, Progressive Taxes, and the Timing of Charitable Contributions. Journal of Political Economy, 103(4):709-738.

Reich, R. (2018). Just Giving: Why Philanthropy Is Failing Democracy and How It Can Do Better. Princeton University Press.

Scharf, K. and Smith, S. (2015). The price elasticity of charitable giving: does the form of tax relief matter? International Tax and Public Finance, 22(2):330-352.

Scharf, K. A., Smith, S., and Ottoni-Wilhelm, M. (2017). Lift and Shift: The Effect of Fundraising Interventions in Charity Space and Time. Technical report.

Seim, D. (2017). Behavioral Responses to Wealth Taxes: Evidence from Sweden. American Economic Journal: Economic Policy, 9(4):395-421.

Urvoy, C. (2020). Political Profit from Nonprofits? Evidence from Governmental Transfers. Working paper.

Vivant, E. (2009). Inconstance du collectionneur ou calcul de l'entrepreneur ?L'échec du projet de fondation François Pinault, révélateur des évolutions des mondes de l'art et de la production urbaine. Politix, 88(4):187-207.

Wand, J. (2007). The Allocation of Campaign Contributions by Interest Groups and the Rise of Elite Polarization.

Yörük, B. K. (2015). Do Charitable Subsidies Crowd Out Political Giving? The Missing Link between Charitable and Political Contributions. The B.E. Journal of Economic Analysis \& Policy, 15(1):1-29. 